\title{
Analisis Kinerja Aparat di Dinas Pendidikan Pemuda dan Olah Raga Propinsi Bali
}

\author{
Kadek Doni Raditya ${ }^{1}$ \\ 1Program Studi Magister Ilmu Ekonomi Universitas Udayana
}

\begin{abstract}
Abstrak
Penelitian ini dilakukan untuk mengetahui pengaruh partisipasi anggaran terhadap kinerja jajaran aparat Dinas Pendidikan Pemuda dan Olah Raga Propinsi Bali, baik secara langsung maupun melalui senjangan anggaran, kejelasan tujuan anggaran, motivasi kerja dan budaya organiasi. Populasi penelitian ini adalah jajaran apparat perangkat Daerah Dinas Pendidikan Pemuda dan Olah Raga Propinsi Bali yang berjumlah 258 aparat. Data dikumpulkan dengan menggunakan kuesioner. Analisis data yang digunakan terdiri dari Uji validitas, uji reliabilitas, uji asumsi klasik, analisis regresi structure equation model SEM dan analisis jalur. Hasil temuan ini dapat disimpulkan bahwa terdapat pengaruh positif partisipasi anggaran terhadap kinerja jajaran aparat Dinas Pendidikan Pemuda dan Olah Raga Propinsi Bali, baik secara langsung maupun melalui senjangan anggaran, kejelasan tujuan anggaran, motivasi kerja dan budaya organiasi
\end{abstract}

Kata Kunci:

Partisipasi Anggaran

Senjangan Anggaran,

Kejelasan Tujuan

Anggaran, Motivasi Kerja

dan Budaya Organiasi

\section{Pendahuluan}

Pelayanan publik dari tahun ke tahun terus mengalami peningkatan tuntutan kepada pemerintah dalam hal ini adalah aparatur negeri, untuk dapat memberikan pelayanan yang optimal kepada masyarakat atau sering dinamakan pelayanan prima, sebagai abdi negara dan abdi masyarakat. Aparatur pemerintah dituntut tanggung jawab yang tinggi dalam memberikan pelayanan kepada masyarakat. Pelayanan publik biasanya diselenggarakan oleh pemerintah, baik pemerintah pusat maupun daerah. Kuatnya tuntutan masyarakat akan pelayanan yang lebih baik memaksa berbagai instansi pemerintah untuk mendorong peningkatan prestasi kerja yang prima. Jadi sukses tidaknya pembangunan nasional tidak lepas dari kualitas dan kemampuan aparatur pemerintah, baik dalam menyelenggarakan tugastugas umum maupun pembangunan. Sehingga dalam pembangunan jangka panjang, pendayagunaan aparatur pemerintah ditempatkan sebagai bagian yang tak terpisahkan dari keseluruhan strategi pembangunan nasional serta dilaksanakan secara konsisten dan berkesinambungan.

Pendayagunaan aparatur pemerintah dalam lima tahun terakhir ini, ditujukan untuk menciptakan aparatur dengan layanan prima, berdaya guna, berhasil guna, bersih dan berwibawa serta mampu melaksanakan tugas-tugas pemerintahan umum dan pembangunan, dilandasi semangat dan sikap pengabdian bagi bangsa, negara dan tanah air, bersifat meneladani, mengayomi dan melayani masyarakat, serta sanggup menumbuhkan prakarsa dan peran serta aktif masyarakat dalam pembangunan yang merupakan pelaksanaan Pancasila dan Undang-undang Dasar 1945. Pendayagunaan tersebut ditujukan pada peningkatan semangat pengabdian, disiplin, kerjasama di dalam suatu dan antar berbagai aparatur, kesetiaan, kemampuan, ketertiban dan kesempurnaan aparatur negara. Hal ini juga sesuai dengan Undang-Undang Nomor 32 Tahun 2004 tentang Pemerintahan Daerah yaitu pemberdayaan aparatur supaya lebih professional, responsif, dan transparan.

Kebijaksanaan pendayagunaan aparatur Pemerintah pertama-tama diarahkan pada peningkatan kecakapan, pengabdian dan kesetiaan kepada cita-cita perjuangan Bangsa dan Negara berdasarkan Pancasila dan Undang-Undang Dasar 1945. Dengan demikian aparatur Pemerintah harus benar-benar merupakan unsur aparatur Negara, abdi Negara dan abdi masyarakat yang cakap dan bermental baik dalam menjalankan tugas umum pemerintahan, tugas pembangunan, serta tugas pembimbingan dan pelayanan kepada masyarakat. Di samping itu langkah-langkah kebijaksanaan pendayagunaan aparatur 
Pemerintah ditujukan pada peningkatan dan pemantapan tata penyelenggaraan pemerintahan yang mencerminkan peranan Pemerintah dalam pembangunan nasional.

Sejalan dengan itu, aparatur Pemerintah harus peka terhadap permasalahan yang dirasakan oleh masyarakat dan cakap dalam mengatasi masalah-masalah tersebut. Oleh karena itu aparatur Pemerintah perlu secara terus menerus ditingkatkan kemampuannya dalam penyelenggaraan fungsi pemerintahan umum dan pembangunan, dalam memberikan rangsangan dan pelayanan kepada masyarakat sehingga timbul prakarsa, kegairahan, serta peran serta aktif mereka dalam proses pembangunan.

Agar tujuan tersebut dapat dicapai, maka aparatur pemerintah hendaknya bekerja secara profesional. Profesionalisme dan keberhasilan aparatur pemerintah dalam melaksanakan tugas dapat dilihat dari kinerjanya di lapangan. Kinerja aparatur pemerintah dalam penelitian ini diartikan sebagai gambaran tentang hasil kerja seorang aparatur pemerintah dalam mengelola dan melaksanakan tugas pendidikan dan pengajaran yang diembannya, didasarkan atas tanggung jawab profesional yang dimilikinya sesuai dengan ukuran yang berlaku bagi pekerjannya. Kinerja aparatur pemerintah tidak terlepas dari paradigma manajemen yang memberikan kewenangan dalam melakukan perencanaan, pengorganisasian, pengawasan, dan pengendalian pendidikan di lembaga. Meningkatkan kinerja aparatur pemerintah bukanlah hal yang mudah, karena harus diketahui terlebih dahulu faktor-faktor apa saja yang mempengaruhi kinerja aparatur pemerintah.

Melihat begitu pentingnya kinerja aparatur pemerintah dalam melaksanakan tugas-tugas profesionalnya, berbagai usaha telah dilakukan pemerintah dalam meningkatkan kinerja aparatur negara diantaranya yaitu: 1) Penyempurnaan peraturan perundang-undangan di bidang keaparaturan; 2) melakukan penyempurnaan formasi aparatur; 3) melakukan pengadaan, Pengangkatan, dan Penyelesaian Kepangkatan Aparatur Negeri; 4) melakukan perbaikan penghasilan aparatur; 5) meningkatkan disiplin aparatur; 6) melakukan komputerisasi dan penyempurnaan tata kelola keaparaturan; 7) meningkatkan kemampuan manajemen dan keterampilan serta produktivitas kerja aparatur negeri; 8) mengadakan berbagai macam pendidikan dan pelatihan keaparaturan, (9) menjaga kesehatan aparatur dan penerima pensiun beserta anggota keluarganya, dan (10) penyempurnaan administrasi.

Berdasarkan uraian dan fenomena tersebut maka peneliti tertarik untuk melakukan penelitian tentang "Analisis Kinerja Aparat Dinas Pendidikan Pemuda dan Olahraga Provinsi Bali." Penelitian ini bertujuan untuk mengetahui (1) pengaruh partisipasi anggaran terhadap kinerja aparat SKPD di Dinas Pendidikan, Pemuda dan Olah Raga Provinsi Bali. (2) pengaruh partisipasi anggaran terhadap kinerja aparat SKPD di Dinas Pendidikan, Pemuda dan Olah Raga Provinsi Bali melalui senjangan anggaran. (3) pengaruh partisipasi anggaran terhadap kinerja aparat SKPD di Dinas Pendidikan, Pemuda dan Olah Raga Provinsi Bali melalui kejelasan tujuan anggaran. (4) pengaruh partisipasi anggaran terhadap kinerja aparat SKPD di Dinas Pendidikan, Pemuda dan Olah Raga Provinsi Bali melalui motivasi kerja. Dan (5) pengaruh partisipasi anggaran terhadap kinerja aparat SKPD di Dinas Pendidikan, Pemuda dan Olah Raga Provinsi Bali melalui budaya organisasi.

\section{Metode}

Penelitian ini merupakan penelitian hubungan kausal (causal effect) yang dilaksanakan di Dinas Pendidikan, Pemuda dan Olah Raga Provinsi Bali pada bulan Januari-September 2013. Populasi dalam penelitian ini berjumlah 258 orang yang terdiri dari Kepala Dinas, Sekretaris dan Kepala Bidang, Kepala Seksi dan Sub Bagian, dan Staf. Sedangkan sampelnya berjumlah 72 orang yang diambil dengan menggunakan pendekatan stratifiedrandom. Proses pengumpulan data dalam penelitian ini menggunakan kuesioner tertutup dengan skala Likert yang mana varibel partisipasi anggaran berjumlah 6 butir, senjangan anggaran berjumlah 6 butir, kejelasan tujuan anggaran berjumlah 3 butir, motivasi kerja berjumlah 6 butir, budaya organisasi berjumlah 5 butir dan kinerja berjumlah 8 butir. Sebelumnya kuesioner tersebut sudah dilakukan validasi pakar dan empirik. Jenis data yang dikumpulkan dalam penelitian ini adalah data primer. Data yang dikumpulkan di analisis dengan menggunakan path analysis untuk menguji hipotesis penelitian.

\section{Hasil dan Pembahasan}

\section{Partisipasi Anggaran Berpengaruh terhadap Kinerja Jajaran Aparat}

Hasil penelitian menunjukkan bahwa partisipasi anggaran berpengaruh positif terhadap kinerja jajaran aparat SKPD di Dinas Pendidikan Pemuda Dan Olah Raga Propinsi Bali. Hal itu dapat dilihat dari kinerja aparat SKPD di Dinas Pendidikan Pemuda dan Olah Raga Propinsi Bali memiliki nilai konstanta sebesar 6,742, sedangkan koefisien regresi partisipasi anggaran bernilai 0,978. Ini menunjukkan bahwa partisipasi anggaran mempunyai hubungan positif terhadap kinerja aparat SKPD di Dinas Pendidikan 
Pemuda dan Olah Raga Propinsi Bali atau, berdasarkan persamaan di atas dapat ditafsirkan secara teoritis bahwa kinerja aparat SKPD di Dinas Pendidikan Pemuda dan Olah Raga Propinsi Bali akan naik apabila terjadi peningkatan pada partisipasi anggaran. Tingkat kesalahan persamaan teoritis di atas dalam memproyeksi kinerja aparat SKPD di Dinas Pendidikan Pemuda dan Olah Raga Propinsi Bali sebesar 0,674 .

Temuan ini sangat sesuai dengan teori yang menyatakan bahwa anggaran sangat memengang peranan penting di sektor publik, hal ini terkait dengan dampak anggaran terhadap kinerja aparat maupun organisasi sektor publik sehubungan dengan fungsi pemerintah dalam memberikan pelayanan kepada masyarakat. Perencanaan dan penganggaran merupakan kegiatan yang saling terintegrasi. Anggaran Daerah (APBD) disusun berdasarkan rencana kerja daerah yang telah disusun baik Rencana Kerja Jangka Panjang (RPJP), Rencana Kerja Jangka Menengah (RPJM) dan Rencana Kerja Pembangunan Daerah (RKPD). Pada tingkat SKPD, anggaran juga disusun berdasarkan rencana jangka menengah SKPD yang sering disebut Renstra SKPD. Renstra SKPD dan RKPD menjadi acuan bagi SKPD untuk menyusun rencana kerja (Renja) SKPD. Agar renja SKPD aspiratif dan memenuhi segala aspek kebutuhan masyarakat, maka renja SKPD disusun dengan cara "duduk bersama/partisipasi" para anggota SKPD serta mengacu kepada RPJP dan RPJM baik nasional maupun daerah. Dengan demikian partisipasi para anggota SKPD memiliki hubungan yang kuat didalam menghasilkan anggaran yang aspiratif dan memenuhi segala aspek kebutuhan masyarakat, dan pada akhirnya akan mempengaruhi kinerja aparat secara individual maupun secara organisasi.

Hasil penelitian ini juga relevan dengan hasil penelitian Milani (1975) yang menemukan adanya pengaruh positif antara partisipasi anggaran dengan kinerja manajer. Brownell (1982) juga menemukan bahwa partisipasi dalam anggaran memiliki pengaruh yang rendah terhadap kinerja manajer, dan dalam pengujian selanjutnya (Brownell dan Mclness, 1986) menemukan bahwa anggaran partisipati memiliki pengaruh positif yang signifikan terhadap kinerja manajer. Peneliti lainnya, Supriyono dan Syakhroza (2003) menemukan partisipasi anggaran berasosiasi positif dengan kinerja manajer. Alfar (2006) menunjukkan bahwa terdapat pengaruh yang signifikan antara partisipasi manajer dalam penganggaran terhadap kinerja baik secara langsung, maupun melalui senjangan anggaran sebagai variabel intervening. Dan Ariadi (2006) menemukan secara langsung partisipasi anggaran memiliki pengaruh negatif terhadap kinerja dan terhadap kepuasan kerja memiliki pengaruh positif, sedangkan secara simultan maupun secara parsial partisipasi anggaran memiliki pengaruh terhadap kinerja dan kepuasan kerja melalui budaya organisasi, gaya manajemen, dan motivasi kerja.

Terkait dengan itu, penelitian ini tidak sejalan dengan hasil penelitian yang dilakukan oleh Kenis (1979) dan Ariadi (2006) yang menemukan bahwa partisipasi anggaran memiliki pengaruh negatif terhadap kinerja. Hasil penelitian dalam penelitian ini menunjukkan bahwa secara deskpritif kinerja aparat SKPD di Dinas Pendidikan Pemuda dan Olah Raga Propinsi Bali berada dalam katekgori sangat baik dan diprediksi mempengaruhi tingkat partisipasi aparat SKPD menjadi sangat baik.

Penelitian mengenai hubungan antara partisipasi anggaran dengan kinerja merupakan penelitian di bidang akuntansi manajemen yang masih dalam perdebatan karena hasil penelitian mengenai hubungan antara kedua variabel tersebut tidak konsisten. Partisipasi dalam penyusunan anggaran diharapkan juga dapat meningkatkan kinerja manajer yaitu ketika suatu tujuan dirancang secara partisipasi dan disetujui maka anggota organisasi akan menginternalisasikan tujuan yang ditetapkan dan memiliki rasa tanggung jawab pribadi untuk mencapainya karena mereka ikut terlibat dalam penyusunan anggaran (Milani, 1975 dalam Listiawati, 2009). Schiff dan Lewin (1970) dalam Tintri (2002) mengemukakan bahwa anggaran yang telah disusun memiliki peranan sebagai perencanaan dan sebagai kriteria kinerja, yaitu anggaran digunakan sebagai sistem pengendalian untuk mengukur kinerja manajerial. Oleh sebab itu implikasinya bagi pimpinan dan aparat di dinas pendidikan pemuda dan olahraga propinsi bali untuk meningkatkan kinerjanya maka harus memperhatikan variabel partisipasi anggaran.

Hasil penelitian ini sejalan dengan hasil penelitian yang dilakukan oleh Arifin, dkk (2012) yang menemukan bahwa partisipasi penyusunan angggaran secara signifikan mempengaruhi kinerja aparatur, dengan karyawan yang berpartisipasi dalam proses penganggaran, mereka juga merasa bertanggung jawab atas keberhasilan program yang sebelumnya telah didiskusikan dengan mereka. Lelly Kewo (2014) juga menemukan bahwa ada pengaruh penganggaran partisipatif, kejelasan sasaran anggaran dan pelaksanaan pengendalian internal secara simultan terhadap kinerja manajerial. Sebagian penganggaran partisipatif, kejelasan sasaran anggaran dan pelaksanaan pengendalian internal masing-masing memiliki pengaruh positif terhadap kinerja manajerial. Dan Rofingatun (2013) menemukan bahwa: (1) ada pengaruh penganggaran partisipatif terhadap keadilan organisasi dan kinerja organisasi, semakin tinggi penganggaran partisipatif, yang bisa mengarah pada tinggi keadilan dan kinerja organisasi, (2) ada pengaruh keadilan organisasi terhadap komitmen organisasi dan kinerja organisasi, keadilan organisasi 
yang tinggi akan berakibat pada komitmen organisasi yang lebih tinggi dan kinerja organisasi, dan (3) ada pengaruh komitmen organisasi terhadap kinerja organisasi, semakin tinggi komitmen organisasi akan menyebabkan dengan kinerja yang lebih tinggi dari organisasi.

Owusu, dkk. (2014) menemukan bahwa temuan penelitian menunjukkan bahwa hubungan antara partisipasi anggaran dan kinerja karyawan (pencapaian sasaran anggaran) positif meskipun tidak signifikan berarti juga bahwa partisipasi anggaran saja tidak dapat secara signifikan mempengaruhi pencapaian sasaran anggaran. Meskipun itu tidak bisa sendirian bantuan sebuah organisasi untuk mencapai tujuan anggaran; itu terbukti dari studi yang berfungsi sebagai dasar untuk elemen perilaku lain yang akan diwujudkan dalam proses penganggaran. Oleh karena itu penelitian berpendapat keluar kuat bagi para pembuat kebijakan untuk palu pada partisipasi anggaran karena merupakan dasar dari mana unsur-unsur perilaku lain untuk mencapai tujuan anggaran berputar. Begitu juga hasil penelitian Mohd Noor, dkk (2012) menunjukkan bahwa partisipasi anggaran berpengaruh signifikan terhadap kinerja manajerial dengan meningkatkan komitmen organisasi. Secara keseluruhan, temuan penelitian memberikan pemahaman yang lebih baik tentang pengaruh partisipasi anggaran di sektor publik, yang memungkinkan pemerintah untuk meningkatkan komitmen organisasi antara karyawan dan memperbaiki proses anggaran sehingga lebih banyak karyawan dapat berpartisipasi. Sebagian besar penelitian tentang partisipasi anggaran telah dilakukan di sektor swasta daripada sektor publik bahkan di negara-negara berkembang. Studi ini mencoba untuk mengisi kesenjangan. Selain itu, penelitian ini mengandalkan partisipatif pendekatan pengambilan keputusan untuk menguji hubungan antara partisipasi anggaran dan kinerja manajerial.

\section{Partisipasi Anggaran Berpengaruh terhadap Kinerja Jajaran Aparat Melalui Senjangan Anggaran}

Penelitian ini menemukan bahwa terdapat pengaruh partisipasi anggaran terhadap kinerja aparat SKPD di Dinas Pendidikan Pemuda dan Olah Raga Propinsi Bali melalui senjangan anggaran. Pengaruh partisipasi anggaran terhadap kinerja aparat SKPD di Dinas Pendidikan Pemuda dan Olah Raga Propinsi Bali melalui senjangan anggaran diprediksi bernilai positif lebih kecil dari pengaruh langsung partisipasi terhadap kinerja aparat SKPD di Dinas Pendidikan Pemuda dan Olah Raga Propinsi Bali, dengan taraf signifikansi $\alpha=5 \%$, hal ini terlihat dari hasil perkalian path (b) dan path (c) =0,989 x 0,325 =0, 321425 lebih kecil koefisien regresi pengaruh langsung partisipasi anggaran terhadap kinerja aparat SKPD di Dinas Pendidikan Pemuda dan Olah Raga Propinsi Bali, yaitu 0.978.

Hasil penelitian ini sesuai dengan pandangan Merchant (1981) yang menyatakan hubungan positif antara partisipasi anggaran dan kinerja manajerial dapat terjadi akibat tingkat partisipasi yang tinggi. Hal ini disebabkan oleh adanya pengaruh senjangan anggaran yang timbul akibat partisipasi yang tinggi dalam penganggaran tersebut. Senjangan anggaran yang merupakan disfungsional dalam penganggaran ini adalah usaha yang dilakukan untuk melonggarkan anggaran dengan harapan dapat mencapai kinerja yang lebih baik. Oleh sebab itu implikasinya bagi pimpinan dan aparat di dinas pendidikan pemuda dan olahraga propinsi bali untuk meningkatkan kinerjanya maka harus memperhatikan variabel partisipasi anggaran.

Hasil penelitian ini diperkuat oleh Frezati (2013) menemukan bahwa kesenjangan anggaran merupakan variabel penting dalam meningkatkan kinerja karyawan. Hal ini dapat dilihat dari tiga temuannya yaitu: yang pertama adalah pemahaman senjangan anggaran sebagai sesuatu yang harus dihindari, dan juga sesuatu yang penting bagi manajemen, yaitu, ketika ada senjangan anggaran akan menguntungkan organisasi. Temuan kedua adalah bahwa pemahaman negatif tentang senjangan anggaran akan berpengaruh negatif terhadap organisasi. Temuan ketiga adalah bahwa argumen untuk tidak adanya senjangan anggaran didasarkan pada struktur yang mempertimbangkan sistem informasi, target yang berasal dari strategi dan keterlibatan intensif manajemen puncak, yang akan menghambat organisasi. Oleh karena itu, organisasi harus memperlakukan kesenjangan anggaran sebagai sesuatu yang harus dikelola, bukan hanya dihindari.

\section{Partisipasi Anggaran Berpengaruh terhadap Kinerja Jajaran Aparat Melalui Kejelasan Tujuan Anggaran}

Hasil penelitian ini menunjukkan bahwamenunjukkan bahwa terdapat pengaruh partisipasi anggaran terhadap kinerja aparat SKPD di Dinas Pendidikan Pemuda dan Olah Raga Propinsi Bali melalui kejelasan tujuan anggaran. Pengaruh partisipasi anggaran terhadap kinerja aparat SKPD di Dinas Pendidikan Pemuda dan Olah Raga Propinsi Bali melalui kejelasan tujuan anggaran diprediksi bernilai positif lebih kecil dari pengaruh langsung partisipasi terhadap kinerja aparat SKPD di Dinas Pendidikan Pemuda dan Olah Raga Propinsi Bali, dengan taraf signifikansi $\alpha=5 \%$, hal ini terlihat dari hasil perkalian path $(\mathrm{d})$ dan path $(\mathrm{e})=0,986 \times 0,270=0.26622$ lebih kecil dari koefisien regresi pengaruh langsung 
partisipasi anggaran terhadap kinerja aparat SKPD di Dinas Pendidikan Pemuda dan Olah Raga Propinsi Bali, yaitu 0.978 .

Hasil penelitian ini mendukung Kenis (1979) yang menguraikan tentang Goal Characteristics salah satu diantaranya adalah kejelasan tujuan anggaran menunjukkan luasnya tujuan anggaran yang dinyatakan secara spesifik dan jelas, dan dimengerti oleh siapa saja yang bertanggung jawab. Kemudian kejelasan tujuan anggaran akan mempermudah aparat pemerintah daerah dalam menyusun anggaran untuk mencapai target-target anggaran yang telah ditetapkan. Komitmen yang tinggi dari aparat pemerintah daerah akan berimplikasi pada komitmen untuk bertanggung-jawab terhadap penyusunan anggaran tersebut. Dengan demikian, semakin jelas sasaran anggaran aparat pemerintah daerah dan dengan didorong oleh komitmen yang tinggi, akan mengurangi senjangan anggaran pemerintah daerah.

Selain itu Schiff dan Lewin dalam Tirtasari (2004), mengemukakan bahwa anggaran yang telah disusun memiliki peranan sebagai perencanaan dan sebagai kriteria kinerja, yaitu anggaran digunakan sebagai sistem pengendalian untuk mengukur kinerja manajerial. Seiring dengan peranan anggaran tersebut, Argyris (1952) dalam Tirtasari (2004) juga menyatakan bahwa kunci dari kinerja yang efektif adalah apabila tujuan dari anggaran tercapai dan partisipasi dari bawahan memegang peranan penting dalam mencapai tujuan tersebut.

Penelitian ini sejalan dengan penelitian Angreini (2014) yang menemukan bahwa kejelasan sasaran anggaran berpengaruh positif tapi tidak signifikan terhadap akuntabilitas kinerja instansi pemerintah pada DIPENDA dan BPKBMD Kota Bitung. Diperlukan penyempurnaan dalam sistem informasi akuntansi keuangan sehingga penyajian informasi lebih tepat, cepat dan bermanfaat bagi pengguna informasi keuangan serta perlu mensosialisasikan tujuan penggunaan anggaran dengan sebaik-baiknya sehingga tidak terjadi penyimpangan dalam penggunaan anggaran. Dan sejalan juga dengan hasil penelitian Lello Kewo (2014) yang menemukan bahwa ada pengaruh penganggaran partisipatif, kejelasan sasaran anggaran dan pelaksanaan pengendalian internal secara simultan terhadap kinerja manajerial. Sebagian penganggaran partisipatif, kejelasan sasaran anggaran dan pelaksanaan pengendalian internal masing-masing memiliki pengaruh positif terhadap kinerja manajerial.

Hasil penelitian ini tidak relevan dengan hasil penelitian yang dilakukan olehSuhartono \& Solichin (2006), menyimpulkan kejelasan tujuan anggaran berpengaruh negatif signifikan terhadap senjangan anggaran instansi pemerintah daerah kabupaten dan kota wilayah Provinsi Yogyakarta.

Oleh sebab itu implikasinya bagi pimpinan dan aparat di dinas pendidikan pemuda dan olahraga propinsi bali untuk meningkatkan kinerjanya maka harus memperhatikan variabel kejelasan tujuan anggaran.

\section{Partisipasi Anggaran Berpengaruh terhadap Kinerja Jajaran Aparat Melalui Motivasi Kerja}

Hasil penelitian ini menunjukkan bahwa partisipasi anggaran berpengaruh positif terhadap motivasi kerja, hal ini terlihat dari tanda positif pada koefisien regresi partisipasi anggaran, yaitu 0,990, yang berarti setiap pertambahan 1 (satu) partisipasi anggaran akan meningkatkan motivasi kerja sebesar 0,990. Sedangkan persamaan 5.7. menginterpretasikan bahwa motivasi kerja berpengaruh positif terhadap kinerja aparat SKPD di Dinas Pendidikan Pemuda dan Olah Raga Propinsi Bali, hal ini terlihat dari tanda positif pada koefisien regresi motivasi kerja, yaitu sebesar 0,472, yang berarti setiap pertambahan 1 (satu) motivasi kerja akan meningkatkan kinerja aparat SKPD di Dinas Pendidikan Pemuda dan Olah Raga Propinsi Bali sebesar 0,472. Hubungan koefisien regresi persamaan 5.1, 5.6 dan 5.7. digambarkan seperti terlihat pada diagram jalur berikut ini.

Hasil penelitian ini sejalan dengan hasil penelitian Sokro (2012) yang menemukan bahwa budaya organisasi memiliki dampak langsung terhadap motivasi kerja karyawan dan tidak langsung pada kinerja organisasi juga. Semakin baik budaya organisasi, semakin tinggi tingkat motivasi karyawan. Telah diamati bahwa jika organisasi mengembangkan budaya yang kuat usaha bermanfaat dan mengakui karyawan, itu mengarah untuk meningkatkan motivasi dan kinerja mereka akan meningkat secara signifikan. Oleh sebab itu implikasinya bagi pimpinan dan aparat di dinas pendidikan pemuda dan olahraga propinsi bali untuk meningkatkan kinerjanya maka harus memperhatikan variabel motivasi kerja.

\section{Partisipasi Anggaran Berpengaruh terhadap Kinerja Jajaran Aparat Melalui Budaya Organisasi}

Hasil penelitian ini menunjukkan bahwa terdapat pengaruh partisipasi anggaran terhadap kinerja aparat SKPD di Dinas Pendidikan Pemuda dan Olah Raga Propinsi Bali melalui budaya organisasi. Pengaruh partisipasi anggaran terhadap kinerja aparat SKPD di Dinas Pendidikan Pemuda dan Olah Raga Propinsi Bali melalui budaya organisasi diprediksi bernilai positif lebih kecil dari pengaruh langsung partisipasi terhadap kinerja aparat SKPD di Dinas Pendidikan Pemuda dan Olah Raga Propinsi Bali, dengan taraf signifikansi $\alpha=5 \%$, hal ini terlihat dari hasil perkalian path (h) dan path (i) $=0,990 \times 0,330=$ 
0.3267 lebih kecil dari koefisien regresi pengaruh langsung partisipasi anggaran terhadap kinerja aparat SKPD di Dinas Pendidikan Pemuda dan Olah Raga Propinsi Bali, yaitu 0.336.

Robert A. Baron (2003) dalam Wibowo (2010) menyatakan budaya organisasi sebagai kerangka kerja kognitif yang terdiri dari sikap, nilai-nilai, norma perilaku dan harapan yang diterima bersama oleh anggota organisasi. Victor S.L. Tan (2002) dalam Wibowo (2010) mendefinisikan budaya organisasi sebagai cara orang melakukan sesuatu didalam organisasi, merupakan serangkaian norma terdiri dari keyakinan, sikap, nilai-nilai inti dan pola perilaku yang dibagikan orang-orang dalam suatu organisasi dan mempengaruhi kinerja organisasi. Menurut Holmes dan Marsden (1996) budaya organisasi mempunyai pengaruh terhadap perilaku, cara kerja dan motivasi para manajer dan bawahannya untuk mencapai kinerja organisasi. Berdasarkan hasil penelitian yang berkaitan dengan budaya, bahwa dimensi budaya mempunyai pengaruh terhadap penyusunan anggaran dalam meningkatkan kinerja anggota organisasi.

Pengukuran kinerja sektor publik adalah suatu sistem yang bertujuan untuk membantu manajer publik atau pimpinan perangkat daerah dalam menilai pencapaian suatu strategi melalui alat ukur finansial dan non finansial. Sistem pengukuran kinerja dapat dijadikan sebagai pengendalian organisasi karena pengukuran kinerja diperkuat dengan menetapkan reward and punishment system. Supomodan Indriantoro (1998) menemukan ada pengaruh positif budaya organisasi yang berorientasi pada orang dan pengaruh negatif pada budaya organisasi yang berorientasi pada pekerjaan terhadap keefektifan partisipasi anggaran dalam peningkatan kinerja manajerial. Ariandi (2006) menemukan terdapat pengaruh yang signifikan antara anggaran partisipatif dengan kinerja manajerial maupun kepuasan kerja melalui budaya organisasi, gaya manajemen dan motivasi kerja.

Hasil penelitian ini sejalan dengan hasil penelitian Darsana (2013) yang menemukan bahwa kepribadian karyawan dan budaya organisasi berpengaruh langsung terhadap kinerja karyawan melalui OCB semua BPR di Gianyar Bali. dan hasil penelitian Sokro (2012) yang menemukan bahwa budaya organisasi memiliki dampak langsung terhadap motivasi kerja karyawan dan tidak langsung pada kinerja organisasi juga. Semakin baik budaya organisasi, semakin tinggi tingkat motivasi karyawan. Telah diamati bahwa jika organisasi mengembangkan budaya yang kuat usaha bermanfaat dan mengakui karyawan, itu mengarah untuk meningkatkan motivasi dan kinerja mereka akan meningkat secara signifikan.

Hasil penelitian ini bertentangan dengan hasil penelitian Syatuka (2012) yang menemukan bahwa budaya organisasi tidak berpengaruh secara langsung terhadap kinerja karyawan. Budaya organisasi dapat mempengaruhi kinerja jika dimediasi oleh kepuasan kerja. Oleh sebab itu implikasinya bagi pimpinan dan aparat di dinas pendidikan pemuda dan olahraga propinsi Bali untuk meningkatkan kinerjanya maka harus memperhatikan variabel budaya organisasi.

\section{Simpulan dan Saran}

Hasil penelitian ini menunjukkan bahwa terdapat pengaruh positif antara partisipasi anggaran terhadap kinerja paratur pemerintah secara langsung maupun tidak langsung melalui senjangan anggaran, kejelasan tujuan anggaran, motivasi kerja, dan budaya organisasi. Oleh sebab itu disarankan Bagi aparat di dinas pendidikan pemuda dan olahraga propinsi Bali agar menggunakan hasil penelitian ini sebagai dasar untuk mengambil kebijakan dalam meningkatkan kinerja aparatnya, misalnya dengan memperhatikan variabel yang berkaitan dengan partisipasi anggaran, kesenjangan anggaran, kejelasan tujuan anggaran, motivasi kerja dan budaya organisasi.

Untuk pengembangan penelitian lebih lanjut agar memperhatikan: (a) variabel lain yang juga mungkin mempengaruhi hubungan antara anggaran partisipatif dengan kinerja manajerial, seperti diantarannya persepsi keadilan, komitmen terhadap tujuan, informasi yang berhubungan dengan pekerjaan (job relevant information), pusat kendali (locus of control) dan lain sebagainya yang belum diungkap dalam penelitian ini. (b) unsur-unsur lain yang terlibat langsung maupun tidak langsung didalam penyusunan anggaran, seperti diantaranya legislatif, unsur muspida, dan lain sebagainya. Dan (c) Instrumen lain yang digunakan untuk mengukur variabel penelitian secara komprehensif sehingga unsur subyektifitasnya menjadi sangat rendah.

\section{Daftar Pustaka}

Agyris, C. (1952). The Impact of Budget on People. The Controllership Foundation,New York.

Alfar R. (2006). "Pengaruh Partisipasi Manajer Dalam Penganggaran Terhadap KinerjaManajerial dengan Budgetary Slack Sebagai Variabel Intervening”.Tesis.Universitas Sumatera Utara, Medan

Angreini Pangumbalerang., S. Pinatik. (2014). Kejelasan Sasaran Anggaran Terhadap Akuntabilitas Kinerja Instansi Pemerintah Pada Dinas Pendapatan Daerah Dan Badan Pengelolaan Keuangan Dan Barang Milik Daerah. Jurnal EMBA Vol.2 No.2 Juni 2014, Hal. 800-808. ISSN 2303-1174 
Ariadi, Dani. (2006). "Pengaruh Anggaran Partisipatif Melalui Budaya Organisasi,Gaya Manajemen, dan Motivasi Kerja Sebagai Variabel InterveningTerhadap Kinerja Manajerial dan Kepuasan Anggaran Pada PT. SocfinIndonesia". Tesis. Universitas Sumatera Utara, Medan.

Arifin, Solikhun dan Rohman, Solikhun. (2012). Pengaruh Partisipasi Penyusunan Anggaran Terhadap Kinerja Aparat Pemerintah Daerah: Komitmen Organisasi, Budaya Organisasi, Dan Gaya Kepemimpinan Sebagai Variabel Moderasi. Jurnal. Diponegoro Journal Of Accounting Volume 1, Nomor 2, Tahun 2012, Halaman 1-11. http://ejournal-s1.undip.ac.id/index.php/accounting.

Darsana, Made. (2013). Pengaruh Kepribadian Dan Budaya Organisasi Pada Kinerja Karyawan Melalui Perilaku Organisasi Kewarganegaraan. The International Journal Of Management ISSN 22775846 Vol 2 Issue 4 (October, 2013).

Frezatti, Fábio., Beck Franciele., Orestes da Silva, Júlio. (2013). Perceptions About The Creation Of Budgetary Slack In A Participatory Budget Process. Journal of Education and Research in Accounting. ISSN 1981-8610. REPeC, Brasília, v. 7, n. 4, art. 1, p. 322-341, Oct./Dec. 2013. Available online at www.repec.org.br

Lelly Kewo, Cecilia. (2014). The Effect of Participative Budgeting, Budget Goal Clarity and Internal Control Implementation on Managerial Performance. jurnal. Research Journal of Finance and Accounting. Www.iiste.org. ISSN 2222-1697 (Paper) ISSN 2222-2847 (Online) Vol.5, No.12, 2014.

Merchant, K.A. (1981). "The Design of Corporate Budgeting System : Influences onManagerial Behavior and Performance". The Accounting Review, p. 813-828.

Milani, K. (1975). 'The Relationship of Participation in Budget Setting to IndustrialSupervisor Performance Attitudes : A. Field Study." Accounting Review.April, p. 274-284.

Mohd Noor, Ida Haryanti Binti., Othman, Radiah. (2012). Budgetary Participation: How It Affects Performance And Commitment. Jurnal. Accountancy Business and the Public Interest 2012. Electronic copy available at: http://ssrn.com/abstract $=2161688$

Rofingatun, Siti ., Idrus, M.S., Salim, Ubud., Djumahir. (2013). Effect Of Budgeting Participation To Justice Organization, Organizational Commitment And Organizational Performance In Papua Hospital. Jurnal. IOSR Journal of Business and Management (IOSR-JBM) e-ISSN: 2278-487X. Volume 8, Issue 2 (Jan. - Feb. 2013), PP 01-06 www.iosrjournals.org

Owusu, Eric Edwin., Dwomoh, Gabriel., Collins, Mintah., Yaa, Gyamfuah., Daniel, Ofori. (2014). Assessing the Relationship between Budget Participation and Employees' Performance of Public Universities in Ghana: a Case of University of Education. Jurnal. International Journal of Academic Research in Accounting, Finance and Management Sciences Vol. 4, No.1, January 2014, pp. 85-95 E-ISSN: 2225-8329, P-ISSN: 2308-0337 (C) 2014 HRMARS www.hrmars.com.

Schiff, M. and A.W. Lewin. (1970). The Impact of People on Budgets. The AccountingReview, Vol. 45, pp. $259-268$.

Sokro, Evans. (2012). Analisis Hubungan Yang Ada Antara Budaya Organisasi, Motivasi Dan Kinerja. Jurnal. Problems of Management iN The 21st Century Volume 3, 2012 ISSN 2029-6932

Sugioyono. (2003). Metode Penelitian Bisnis. Alfabeta, Bandung.

Suhartono, Ehrmann \& Mochammad Solichin. (2006). "Pengaruh Kejelasan SasaranAnggaran Terhadap Senjangan Anggaran Instansi Pemerintah Daerah DenganKomitmen Organisasi Sebagai Pemoderasi". Simposium Nasional AkuntansilX, Padang.

Supriyono, R. A. \& Akhmad Sykhroza. (2003). “Peran Asimetri Informasi danPeresponan Keinginan Sosial Sebagai Variabel Moderating Hubungan AntaraPartisipasi Penganggaran dan Kinerja Manajer di Indonesia". SimposiumNasional Akuntansi IV, Surbaya.

Syauta, Jack Henry,. Troena, Eka Afnan., Setiawan, Margono, Solimun. (2012). Pengaruh Budaya Organisasi, Komitmen Organisasi terhadap Kepuasan Kerja dan Kinerja Karyawan (Studi pada PDAM Jayapura, Papua Indonesia) International Journal of Business and Management Invention ISSN (Online): 2319 - 8028, ISSN (Print): 2319 - 801X www.ijbmi.org Volume 1Issue 1 ||| December. 2012 |||| PP.69-76. www.ijbmi.org 